\title{
How Covid-19 Could Trigger Organisational Innovation in Education
}

\author{
Luc Soete*1 \\ Professor, Brussels School of Governance, VUB, Belgium and Maastricht University, Netherlands
}

Submission: March 29, 2021; Published: April 05, 2021

"Corresponding author: Luc Soete, Professor, Brussels School of Governance, VUB (Free University of Brussels), Belgium and Maastricht University, Boschstraat 246211 AX Maastricht, The Netherlands

"There is enormous inertia - a tyranny of the status quo - in private and especially governmental arrangements. Only a crisis - actual or perceived produces real change. When that crisis occurs, the actions that are taken depend on the ideas that are lying around [2]."

\section{Introduction}

The COVID-19 pandemic has accelerated in a significant way many forms of organisational innovation, particularly in services areas which crucially depended on physical contact and social interactions between service delivery and service consumption, and which became suddenly confronted with radical measures enforcing social distancing. Undoubtedly, in many of those areas where physical contact is the essence of the service, one can expect a gradual return to "normal" following vaccination. But in others, the new, virtual alternative organisation forms which already existed but had not widely diffused, became, with the outbreak of the COVID-19 pandemic, an organisational innovation to stay. The dramatic growth in home delivery of goods/services - with e.g. restaurants becoming delivery-only, "dark kitchens" - is probably the best example.

In a certain sense, the COVID-19 pandemic has made one rediscover the value of proximity. It has increased the value of local physical contacts at the expense of distant ones with amongst others a blossoming of local circular economy initiatives [3]. At the level of work, it has made one aware of the cost of travelling and commuting with online work taking-off, and sometimes radically shifting the "work place" from a distance to a local environment.

This process of rediscovering the value of proximity, raises at a more fundamental level, the question put forward by Bowles and Carlin [4] whether the COVID-19 pandemic might not force us to look much more explicitly at the local economy. More precisely, at the social norms in all those local areas of primarily non-market social interactions which characterize the local environment, such as health and social care, education and childcare and a number of key public services, all considered essential services during the pandemic. In short, what could be called, local civil society. The social norms in such local communities do not always fit well the traditional government versus market dichotomy but are often rather based on other values such as reciprocity, fairness, sustainability, identity, sometimes even altruism. As Bowles and Carlin [5] put it: "this third pole - community or civil society - expands the state space for policies by drawing on ethical motivations of solidarity and duty that underpin community and going beyond material gain and compliance with governmental fiat [5]."

In this short opinion piece, we focus on one such area of physical contact, non-market "service" delivery which was abruptly subject to social distancing and forced to re-organize itself in a sometimes purely virtual way: education. An area where there is widespread agreement that the costs to society of school closure, is and has been huge. The OECD estimated that, under the assumption of a one-third of a year lost in schooling: "the present value of the total cost would amount to $69 \%$ of current GDP for the typical country [6]." The OECD report was written in the summer of 2020 and covered the 2019-2020 school year. At best, the onethird year school loss repeated itself in the 2020-2021 school year with the onslaught of the second wave of the COVID-19 pandemic.

\section{From physical to digital education: how schools became unequal as never before}

The impact on individual youngsters of school closure was significant. Initially, the assumption was that a fast replacement of physical education with digital education would solve most of the school closure problems. The policy focus was on guaranteeing availability of high-speed internet connection and laptops for every pupil. But this was clearly not a sufficient condition for providing an appropriate "e-school" learning environment. It is not because today many, if not most youngsters have such access and are familiar with online exchanges, that sufficient pedagogically based education can be provided. Overall, youngsters represent a major, long-term, collateral damage factor of too generic lockdown measures introduced both during the first and subsequent waves of the COVID-19 pandemic. 
At the same time, it is not so much the digital provision of education which is to blame for such damage, than the simple fact that, because of the lockdown, schools no longer could play their role of physical meeting place for youngsters to interact and learn to socialize within structured, regular time frames with teachers as both learning authority and knowledge sparring partners. From this perspective, the COVID-19 pandemic reveals quite abruptly, the diverse, other functions and contributions of schooling, from primary schools to universities. That of providing, next to the organization of education, of a physical, local environment for youngsters to learn to socialize amongst people of the same age, to separate fact from opinion, to develop a local identity as part of a community and more generally to become better prepared to make life choices. In short, schools are much more than education establishments.

Can we though draw also some more practical lessons? Could e.g. the COVID-19 pandemic not engender a more radical transformation of our education systems into a more hybrid structure? As the authors of the OECD study Hanushek and Woessmann [6], already mentioned above, observe:" while it has yet to be analysed rigorously, some teachers are undoubtedly better than others at providing video-based instruction, while others are more effective at providing in-person instruction. Policies that recognise differences in effectiveness and that use more effective teachers in a better manner would improve overall school performance". In short, could one not exploit more systematically the best practice "video-based" teacher performance in a digital teaching setting at e.g. national level; and by contrast organize physical education in schooling establishments with a stronger focus on in-person instruction providing the physical environment for application, for individual evaluation and for social interactions. To get a better idea on how this could be done, it might be good to have a closer look at organisational innovations in the past.

\section{Lessons from History}

As economic historians such as Paul David [7] or innovation economists such as Christopher Freeman [8] have highlighted, organisational change played a major, if not the major role in the diffusion of electricity during the 1920's. The initial introduction of electricity in factories in industry did not lead to any major efficiency gains. On the contrary, the simple replacement of steam power with electricity led to quite similar problems of breakdowns; the electric engines being more or less structured in a similar way to the old steam engines as the central energy source on which all machines would dependent. The real breakthrough only came much later with the organisational discovery that electricity could be used as energy source for each separate machine, so-called unit electric drive. Only then did automation and the assembly line production take really off. Quite suddenly one discovered that with machines driven separately by electricity, one could achieve much greater flexibility in the layout of machines in the factory with large capital savings in floor space. As Freeman noted: "The full expansionary and employment benefits of electric power on the economy dependent, therefore, not only on a few key innovations in the 1880s or on an 'electricity industry' but on the development of a new 'paradigm' or production and design philosophy [7]."

In the case of education it could be argued that the introduction of digital technologies during the COVID-19 pandemic, in a similar fashion to electricity, simply tried to imitate physical education: a home e-school with the teacher at a distance and pupils or students listening each from their home place. Given the sudden outbreak of the COVID-19 pandemic, there was of course no time for schools to raise more fundamental pedagogical questions such as the extent to which particular learning activities might depend more on physical presence and others in which pupils could learn as well at a distance, e.g. in interaction with educational software. And at which age, this might be most opportune.

As in the case of electricity, organizational inertia took over: physical education became digital education in the same organizational setting with classic timetables being converted into online events. Every school's teachers and pupils quickly mastered existing, available online video systems to call in and listen to the topics lectured, keeping the lesson framework intact.

\section{Organisational Innovation in Education}

The claim made here is that, in a similar vein to the paradigm and design shift which occurred in the case of unit electric drive, one should focus today on the design of a radically different, more flexible, hybrid education format system based on pedagogical insights and digital didactics. Such new hybrid forms will offer more possibilities to differentiate between students combining partial distance learning and contact education allowing for a greater diversity at schools: diversity in terms of talents, cognitive skills, maturity, prior knowledge, language [9]. In short, making schools and education more inclusive, exploiting more fully the need for a more differentiated teaching and learning model. Up to now, digital education, as introduced during the COVID-19 pandemic had more or less the opposite impact: increasing existing inequalities between schools and between pupils.

Despite the much greater use of digital education tools in higher education, the challenge is broadly similar for higher education. The 'real' paradigm change will again consist of a common offer of "best practice" digital courses starting with traditional STEM (Science, Technology, Engineering and Mathematics) courses across higher education institutions, freeing the time of teachers to do exercises with, and assess the progress of individual students. This requires of course first and foremost cooperation between higher education institutions, rather than competition as is generally the rule today. Interestingly, in a recent study of PWC [10] on the cost efficiency of higher education in the Netherlands, the current financial shortfall of Dutch universities in providing high quality education given the significant growth in student population, was 
estimated at some 1,1 billion euro; a figure broadly in line with what the universities had also estimated themselves. However, as also pointed out in the study, in an alternative scenario based on close collaboration between universities in providing hybrid, blended learning education, most of this financial shortfall would be covered.

Furthermore, the current, pre-corona evidence on various hybrid forms of education, highlights that such "blended learning" education forms do actually not lead to any lower study performance than physical education [11]. On the contrary, combining physical and online education appears to lead on average to marginally better study performance. This seem to hold for both pupils in primary and secondary education as well as for students in higher education. And it seems also valid for all subject fields. In the Dutch PWC study mentioned above, it has been argued that the average student staff class ratio could, as a result of applying such blended learning methods, be increased by a factor of two [12].

But it has also been shown that in their first applications, these hybrid, blended learning applications rarely lead to immediate efficiency gains. In a similar way to the diffusion of electricity in the late 19th and early 20th Century in the US, when, as analyzed by Paul David and Gavin Wright (2001), productivity, and in particular capital productivity declined and only started to increase after the first World War, the diffusion of digital education tools is likely to lead initially to higher development and digital equipment capital costs, as well as significant learning and training costs on the part of both staff and students. Subsequently though, and depending on their design, combinations of face to face, physical contact and digital education forms are likely to lead to higher efficiency and better study performance. Interesting from this perspective is the evidence with respect to the impact of the so-called "flipped classrooms" $[13,14]$, educational methods involving pupils and students more actively ahead of the social class gathering, in the study and preparation of learning material. As recent evidence collected by Van Alten et al. [15] illustrates, success will crucially depend on the design. E.g. when face-to-face class time is not reduced compared to a non-flipped classroom environment or when "quizzes" are added in the flipped classrooms, better study performance will be achieved. Again, the historical parallelism with the organisational design innovation of unit electric drive is striking.

\section{Conclusion}

The outburst of the COVID-19 pandemic and the ensuing school lockdown measures taken revealed the limits of organisational innovation in education confronted suddenly with having to limit social contacts between pupils, students and teachers. Fully, online education models designed using the physical class model as organisational set-up and organized in a couple of weeks' time, were totally inappropriate to compensate for school closures. As an educational tool, online education will have to be guaranteed by universal access to internet for all pupils and students. Second, digital didactics should guide the organisational design of digital education enabling diverse combinations of distant learning and contact education, making schools more inclusive. Today, distance learning with more skilled parents being in a better position to offer the necessary complementary face-to face personal attention and motivation to their own children, has been a source of wide and increasing gaps in learning between pupils and students of different socioeconomic origins.

The organisational innovation which education systems across the world could benefit from following the COVID-19 pandemic, consists of exploiting in a more flexible and hybrid way best practice online education to the benefit of a more inclusive school and learning system. Schools - both as an institution as well as a building - represent in many ways our last chance for the promotion of social equality: allowing for exchanges amongst youngsters with different social background. Giving explicitly schools the tasks of providing access to best practice digital education and freeing time for physical education addressing "face to face" socially isolated pupils and students from poorer and more marginalized neighbourhoods could be a lasting, major organisational innovation resulting from the COVID-19 pandemic.

To conclude, a final remark. Does the epigraph from Milton Friedman fit the organisational set up of education in schools? Friedman's quote, made within a totally different context, suggests that a crisis might be the best moment to reflect on ideas that lay around but also warns us of the tyranny of the status quo, particularly in areas dominated by governmental arrangements. School education fits the bill on both accounts.

\section{References}

1. Luc Soete is Dean of the Brussels School of Governance at the VUB, Belgium and Honorary Professor, Maastricht University, The Netherlands.

2. Milton Friedman (1982) Capitalism and Freedom, University of Chicago Press, London, preface, p. xiv.

3. See e.g. the emergence of AI localism.

4. Bowles Samuel, Wendy Carlin (2020a) Shrinking Capitalism. AEA Papers and Proceedings 110: 372-77.

5. Bowles Samuel, Wendy Carlin (2020b) Economics and the pandemic - what will we have learned? International Science Council, Webinar.

6. Hanushek E, Woessmann L (2020) The Economic Impacts of Learning Losses, OECD.

7. David P (1990) The Dynamo and the Computer: An Historical Perspective on the Modern Productivity Paradox. American Economic Review 80 (2): 355-361.

8. Freeman C (1987b) Information Technology and Change in TechnoEconomic Paradigm. In Freeman C, Soete L (Eds.), Technical Change and Full Employment, Basil Blackwell, Oxford, 49-69.

9. See Yves Demaertelaere (2021) learning has left the school.

10. PWC (2021) Toereikendheid, doelmatigheid en kostentoerekening in het mbo, hbo en wo\&o (Adequacy, efficiency and cost allocation in mbo, hbo en wo\&o.

11. Escueta M, Quan V, Nickow AJ, Oreopoulos P (2017) Education Technology: An Evidence-Based Review. NBER Working Paper 23744. 


\section{Annals of Social Sciences \& Management studies}

12. See also Alpert WT, Couch KA, Harmon OR (2016) A Randomized Assessment of Online Learning, American Economic Review 106(5): 378-382.

13. Halverson L, Spring KJ, Huyett S, Henrie CR, Graham CR (2017) Blended learning research in higher education and K-12 settings, Learning, Design and Technology, pp. 1-30.

14. In a flipping the classroom approach, students study instructional material before class by watching online lectures or reading the material before and then applying the material learned during class. Maastricht university following McMaster, has introduced since its creation such flipped classroom approaches since 1976.

15. Alten van D, Phielix C, Janssen J, Kester L (2019) Effects of flipping the classroom on learning outcomes and satisfaction: A meta-analysis, Educational Research Review, 28: 100281.

\begin{tabular}{|l|}
\hline \multicolumn{1}{|c|}{ Your next submission with Juniper Publishers } \\
will reach you the below assets \\
- Quality Editorial service \\
- Swift Peer Review \\
- Reprints availability \\
- E-prints Service \\
- Manuscript Podcast for convenient understanding \\
- Global attainment for your research \\
- Manuscript accessibility in different formats \\
( Pdf, E-pub, Full Text, Audio) \\
- Unceasing customer service \\
Track the below URL for one-step submission \\
https://juniperpublishers.com/online-submission.php \\
\hline
\end{tabular}

